\title{
Pregnancy diagnosis in Black Bengal goat by progesterone assay
}

\author{
MM I slam ${ }^{1}$, K Kizaki ${ }^{2}$, Takahashi $^{3}$, JS Khanom ${ }^{1}$, S Debnath ${ }^{1}$, MAMY Khandoker* ${ }^{1}$
}

${ }^{1}$ Department of Animal Breeding and Genetics, Bangladesh Agricultural University, Mymensingh 2202, Bangladesh; ${ }^{2}$ Iwate University, Japan; ${ }^{3}$ National Institute of Agro-biological Sciences, Tsukuba, Japan

\begin{abstract}
Pregnancy is the main event in the life of a female mammal to reproduce the progeny and maintain the descents of the species. Progesterone level in the plasma is one of the indications of stages of pregnancy of an individual and the present study was undertaken to determine the progesterone level in different stages of pregnant Black Bengal does and to correlate blood progesterone level with stages of pregnancy in Black Bengal does. For this experiment the blood samples were collected from different stages of pregnant and non-pregnant Black Bengal does, kids and bucks, and subjected to use for further study. The progesterone level was measured at 3 different stages of pregnancy (25-30 days, 60- 70 days, and 90-92 days) using the test kit (EIA TEST KIT Progesterone, Biocheck, Inc. Foster city, CA 94404 USA). Progesterone was also assayed in different ages of non-pregnant does, kids and bucks blood as the control. The logarithmic graph paper was used to calculate the progesterone level. The progesterone levels were found $1.5 \mathrm{ng} / \mathrm{ml}, 6.6-9.3 \mathrm{ng} / \mathrm{ml}$ and $14-15.5 \mathrm{ng} / \mathrm{ml}$ in 25-30 days, 60-70 days and 90-92 days of pregnancy, respectively. In case of non-pregnant does the progesterone level varied from 0.19$6.6 \mathrm{ng} / \mathrm{ml}$ in different ages. Whereas the progesterone level was found between $<0.1 \mathrm{ng} / \mathrm{ml}$ and 4.4 $\mathrm{ng} / \mathrm{ml}$ in kids blood samples and in case of bucks the progesterone level was $<0.1 \mathrm{ng} / \mathrm{ml}$. So, it is clear that the progesterone level simultaneously increased as the stages of pregnancy advanced in the blood of pregnant Black Bengal does.
\end{abstract}

Key words: Blood progesterone, ELISA, goat, pregnancy

Bangladesh Animal Husbandry Association. All rights reserved. Bang. J. Anim. Sci. 2014.43 (3): 180-184

\section{I ntroduction}

Black Bengal goat is the only recognized goat breed in Bangladesh. It is a dwarf breed and famous for its high fertility, prolificacy, superior chevon quality, best quality skin, early sexual maturity, disease resistance, low kidding interval and adaptability (Devendra and Burns, 1983). Early detection of pregnancy is of considerable economic value to goat industry. Early pregnancy diagnosis tends to improve life time productivity of the enterprise. Non pregnant does could be marketed at higher price than they would bring as mature does thus reducing feed expenses (Gearhart et al. 1988). The intensive goat management and the wide spread application of the controlled breeding techniques, such as artificial insemination and out-of seasonal breeding; increase the need for an accurate and practical test for early pregnancy diagnosis. The traditional methods such as non-return to estrus and abdominal ballottement are not satisfactory.
In addition, laparotomy, laparoscopy, rosette inhibition test and vaginal biopsy are accurate techniques; however these methods are impractical under farm conditions (Goel and Agrawal 1992; Gordon 1999). Accurate pregnancy diagnosis may provide essential information for effective herd management practices (Doize et al. 1997). Actually, the main aim of pregnancy diagnosis is to detect with certainty the non pregnant animals as early as possible. Traditional indirect methods for pregnancy diagnosis in small ruminants are palpation through external abdomen and noting udder enlargement. But no direct methods are available for pregnancy diagnosis in small ruminant like goat. The $\mathrm{CPL}$ (caprine Placental Lactogen) and CPRP-1 (caprine Prolactein Related Protein) may be used as candidate gene in pregnancy diagnosis in Black Bengal goats (Debnath 2012). Moreover, the histological study indicates that fetal connective tissue, maternal connective tissue and epithelium trophoblast 
increase during 50 days of pregnancy and decrease during 90 days of pregnancy in Black Bengal goats (Khanam 2012). Measurement of blood progesterone concentration is a reliable indicator of the presence of functional corpus luteum (Rahman 2002). In this perspective, progesterone hormone assay might be effective method to confirm the stage of pregnancy in Black Bengal goat because progesterone hormone is a pregnancy hormone. It is evident that as pregnancy advances, the progesterone level in the blood might increases to certain level. With this idea in view, the objectives of the present study were to determine the progesterone level in different stages of pregnant Black Bengal does and to correlate blood progesterone level with stages of pregnancy in Black Bengal does.

\section{Materials and methods}

The blood samples were collected from the pregnant does, non-pregnant does, kid, and mature buck derived from USDA funded conservation of Black Bengal goat project, Department of Animal Breeding and Genetics, Bangladesh Agricultural University (BAU). Total 12 samples were collected from pregnant does of different stages, 4 from kids, 4 from nonpregnant does, and 4 from mature bucks. Blood was taken from jugular vein using venoject tubes coated with heparin which served as anticoagulant. Complete experiment protocol is shown in flow diagram in Figure 1

Immediately after collection of blood, it was transferred to the centrifuge machine with a capacity of $3000 \mathrm{rpm}$. The blood sample was centrifuged for 30 minutes at $3000 \mathrm{rpm}$ for the first time. After centrifugation $200 \mu \mathrm{l}$ plasma sample was collected from each tube. Then recentrifugation of collected plasma was done in a reaction tube at $4^{\circ} \mathrm{C}$ at $3000 \mathrm{rpm}$ for 90 minutes. Then the plasma was transferred into new reaction tubes. After transferring the plasma in the new reaction tubes, they were kept at $4^{\circ} \mathrm{C}$ for overnight.

Before preparing the working solution the test kit was kept at room temperature for 10 minutes as it was stored in $4^{\circ} \mathrm{C}$. HRP working solution was prepared by adding of $0.5 \mathrm{ml}$ conjugate concentrate into $5 \mathrm{ml}$ diluents dispense. Then it was kept in a tube rack for further use.

After preparing the HRP working solution the vials were prepared. To prepare the vials, the standard vials were arranged in order of $0,0.5,3.0,10,25$ and $50 \mathrm{ng} / \mathrm{ml}$. Six standards were added chronologically each of them in two vials at $25 \mu \mathrm{l}$ per vial. After adding of standards the control plasma was added. There were two levels of control-1 and 2. Each level was added in two vials at $25 \mu \mathrm{l}$ per vial. Then 12 samples were added in 24 vials having $25 \mu \mathrm{l}$ per vial. Then 100 $\mu \mathrm{l}$ HRP dispensed working solution was added in each vial. After that $50 \mu \mathrm{l}$ dispensing antibody was added in each vial as same as HRP solution. Then the whole vial was covered with scostape to prevent evaporation. Then the whole vial was mixed by jerking for about 30 seconds. Then the whole vial was remained at room temperature for about 90 minutes for incubation.

After the incubation of 90 minutes the whole vial was washed for five times with distilled water by micro plate washer. Then the whole vial was wiped out with tissue paper.

After wiping of the whole vial, $100 \mu \mathrm{l}$ TMB reagents was added to each vial. Then the whole vial was mixed gently for 10 seconds and incubated at room temperature for 20 minutes in a dark place as TMB reagent is light sensitive. During the incubation the color was turned into light blue to deeper blue. After that $100 \mu \mathrm{l}$ stop solution was added in each vial. The color of the vials was light yellow after loading the stop solution. Then the whole vial was shacked for 30 seconds and it was ready for ELISA (Enzyme linked immune-Sorbent Assay).

ELISA was read out by the ELISA reader for 0 , $0.5,3,10,25,50$ standards at the rate of 450 $\mathrm{ng} / \mathrm{ml}$. The ELISA was performed at professor Muhammed hossain Central Laboratory, Bangladesh Agricultural University, Mymensingh. After measuring the absorbance level by the ELISA reader, it was then ready to calculate the progesterone concentration. Firstly the absorbance values of the two vials from each sample were placed in Microsoft Excel work sheet and the average value was calculated. The 


\section{Pregnancy diagnosis in goat}

average values were then placed in the logarithmic graph paper and the straight line was drawn covering the maximum points and finally the progesterone level was recorded.

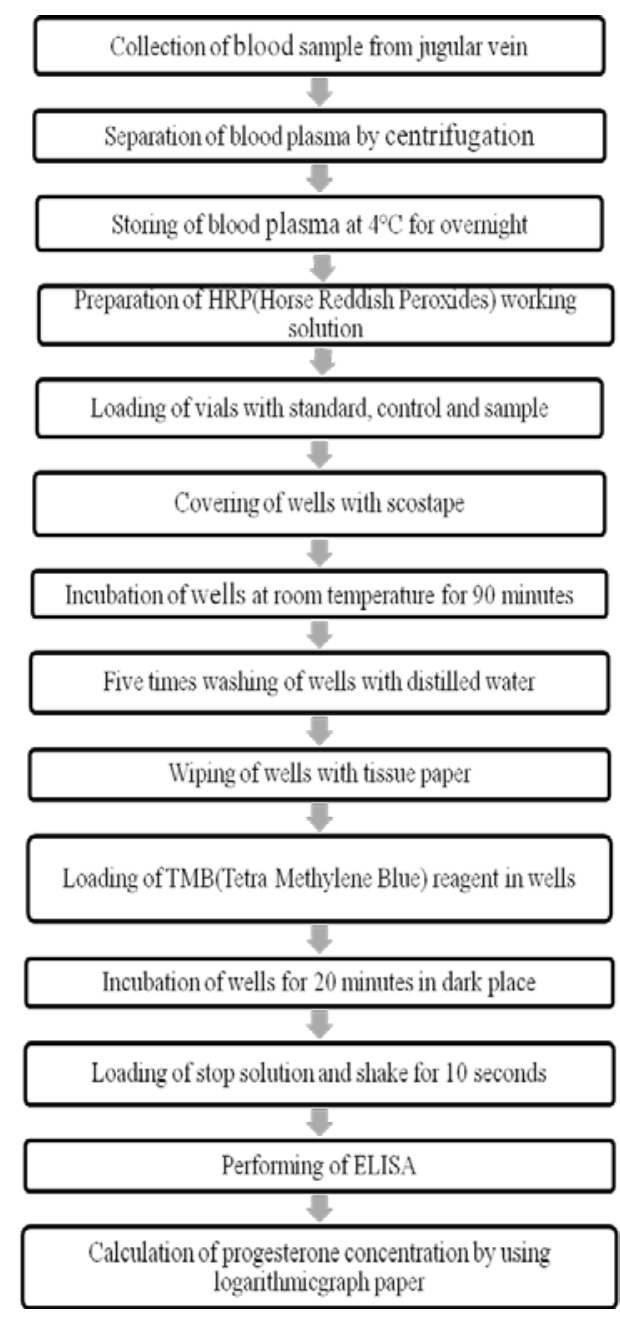

Figure 1. Flow diagram of the experimental protocol

The data generated from this experiment were entered in Microsoft Excel worksheet, organized and processed for further analysis. Analysis was performed with the help of SPSS program 16.0. The mean values were calculated with regard to different pregnancy stage to observe the significant difference among different progesterone values using paired sample t-test.

\section{Results and Discussion}

The present study was done to determine the progesterone level at the different stages of pregnancy of Black Bengal goat. The result of the progesterone level of different, non-pregnant does, kids and mature bucks is shown in the Table 1.

Table 1. Mean $\pm \mathrm{SE}$ of progesterone in different sex and stages of pregnant goat

\begin{tabular}{lcc}
\hline $\begin{array}{l}\text { Sex and types of Black } \\
\text { Bengal goat }\end{array}$ & $\begin{array}{c}\text { No. of } \\
\text { observations }\end{array}$ & $\begin{array}{c}\text { Progesterone level } \\
(\mathrm{ng} / \mathrm{ml})\end{array}$ \\
\hline Mature buck & 4 & $<0.1$ \\
Kids & 4 & $1.54 \pm 1.42$ \\
Non-pregnant does & 4 & $3.96 \pm 1.88$ \\
\hline Pregnant does with stages & & \\
25-30days & 3 & $1.5 \pm 0$ \\
60-70days & 6 & $8.5 \pm 0.80$ \\
90-92days & 3 & $14.5 \pm 0.44$ \\
\hline
\end{tabular}

The progesterone level differed significantly among the stages of pregnancy; between 25-30 days and 60-70 days $(p<0.05)$; between $60-70$ days and 90-92 days $(p<0.01)$; between 25-30 days and 90-92 days $(p<0.01)$. This result clearly demonstrated that progesterone profile varies due to advancement of stages of pregnancy in Black Bengal goats.

Three non-pregnant does were used in this experiment and their ages were also different. Less amount of progesterone found in nonpregnant animals in the present study is very usual and the variation of progesterone level might be due to variation in ages. From the above result we can easily understand that as the pregnancy advances the progesterone level increases simultaneously in blood. This advancement is shown in the Figure 2 in linear graphical presentation.

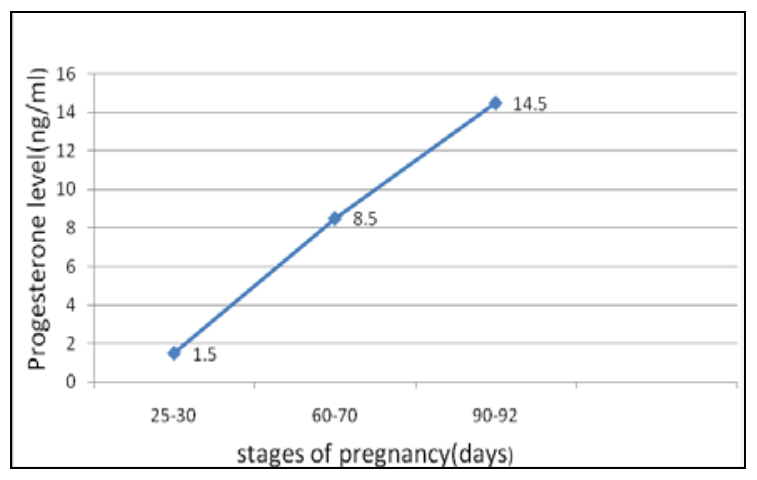

Figure 2. Relationship between stages of pregnancy and progesterone level in graphical presentation 
The result of the present study agrees with Alwan et al. (2010). They reported that levels of progesterone hormone increased during first and second months in ewes and does, while the significant increased from third month on-ward and it is useful means in diagnosis pregnancy of ewes and does by hormonal methods after 20-30 days of mating. Again the pregnancy diagnosis by hormone assay agrees with Amezcua-Moreno (1988). According to him the accuracy of enzyme immune assay for detecting pregnancy is high while it is low for diagnosing of non-pregnancy. In this regard Zarkawi (1997) reported that $100 \%$ accuracy for detecting non pregnant ewes was achieved by using ElA (Enzyme Immuno Assay) at day 21 after mating. In this aspect Gonazelz et al. (2003) reported that progesterone assay give the accurate results at 22 days of pregnancy in Canary dairy goats. The result of the present study contradicts with Butler et al. (1981). They reported that the progesterone content of the Hampshire ewes in late pregnancy were $6.53 \mathrm{ng} / \mathrm{ml}$ and $8.54 \mathrm{ng} / \mathrm{ml}$ for single and twin litter size, respectively. The contradiction may be due to species difference.

Table 2. Progesterone level in non-pregnant does at different ages of the does

\begin{tabular}{ll}
\hline $\begin{array}{l}\text { Age of non-pregnant does } \\
\text { (Month) }\end{array}$ & $\begin{array}{l}\text { Progesterone level } \\
(\mathrm{ng} / \mathrm{ml})\end{array}$ \\
\hline 10 & 0.19 \\
21 & 5.7 \\
52 & 6.0 \\
\hline
\end{tabular}

From the above result it is clear that the progesterone level of mature non-pregnant does is in higher increment due to increase the age of the animals. This finding reflects that age of Black Bengal goat which might be one of the indicators of the development of corpus luteum in cyclic non-pregnant does. The result of the present study as shown in Table 2 agrees with Alwan et al. (2010). They reported that during the estrous cycle in small ruminant, the plasma progesterone concentration was found to be 9.3 $\mathrm{ng} / \mathrm{ml}$ and varied from 2 to $18 \mathrm{ng} / \mathrm{ml}$.

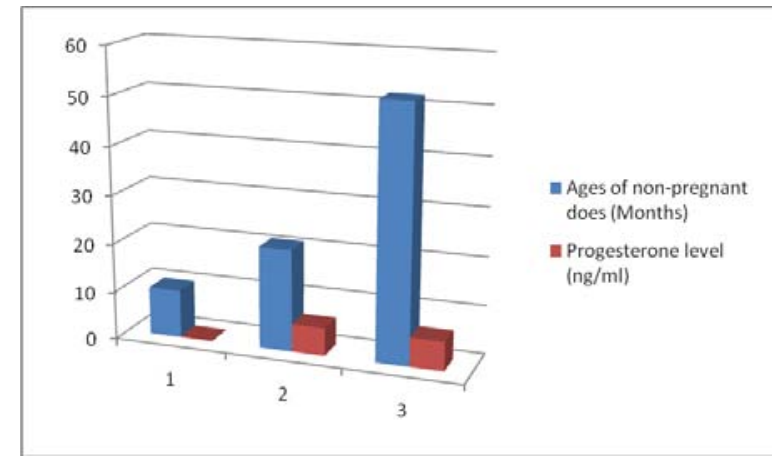

Figure 3. Relationship between ages of non-pregnant does and progesterone level

Table 3. Blood progesterone level in kids at different ages

\begin{tabular}{ll}
\hline Age of kids (Day) & Progesterone level $(\mathrm{ng} / \mathrm{ml})$ \\
\hline 44 (Female) & 0.13 \\
114 (Male) & $<0.1$ \\
201 (Female) & 4.4 \\
\hline
\end{tabular}

From the Table 3 found that the kids were at 44 days of age the progesterone level was found $0.13 \mathrm{ng} / \mathrm{ml}$, at 114 days $<0.1 \mathrm{ng} / \mathrm{ml}$ and at 201 days $4.4 \mathrm{ng} / \mathrm{ml}$. This result might be due to difference in ages, sexes and body conditions of the kids.

\section{Conclusions}

Progesterone is detected as the pregnancy hormone and it is clear that as the stages of pregnancy advances the progesterone level simultaneously increases in the blood of Black Bengal goats. Thus the method of detection of pregnancy can be used for optimizing production profile of Black Bengal goat as early pregnancy diagnosis tends to improve lifetime productivity of the enterprise.

\section{References}

Alwan AF, Amin FAM, I brahim NS (2010). Blood progesterone and estrogen hormones level during pregnancy and after birth in Iraqi sheep and goat. Bangladesh Journal of Animal Science, 10: 2

Amezcua-M MDR (1988). Pregnancy diagnosis in ewes by means of the determination of blood progesterone concentration on Day18 


\section{Pregnancy diagnosis in goat}

after insemination using enzyme immunoassay. Veterinary Mexico, 19: 386

Butler WR, Fullenkamp SM, Cappielo LA, Handswerger (1981). The relationship between breed and litter size in sheep and maternal serum concentrations of placental lactogen, estradiol, and progesterone. Journal of Animal Science, 53: 4

Debnath S (2012). Identification of Pregnancy related genes in Black Bengal goat. MS Thesis, Department of Animal Breeding and Genetics, Bangladesh Agricultural University.

Devendra C, Burns M (1983). Goat production in the tropics, second edition. Commonwealth Agricultural Bureaux, Farnham Royal, Slough, UK. P. 64- 65.

Doize F, Vaillancourt D, Carabin H, Belanger D (1997). Determination of gestational age in sheep and goats using transrectal ultrasonographic measurement of placentomes. Theriogenology, 48: 449460.

Gearhart MA, Wingfield WE, Knight AP, Smith JA, Dargatz DA, Boon JA, Stokes CA (1988). Real-time ultrasonography for determining pregnancy status and viable fetal numbers in ewes. Theriogenology, 30: 323-337.
Goel AK, Agrawal KP (1992). A review of pregnancy diagnosis techniques in sheep and goats. Small Ruminant Research, 9:255-264.

Gonazelz F, Cabrera F, Batista M, Noemi R, Alamo D, Sulon J, Gracia A (2003). A comparison of diagnosis of pregnancy in the goat via transrectal ultrasound scanning, progesterone, and pregnancy-associated glycoprotein assays. Theriogenology, 12: 09

Gordon I (1999). Pregnancy testing in sheep. In: Controlled Reproduction in Sheep and Goats. Gordon I. (ed.) New York, CABI International, P. 241-259.

Khanam JS (2012). Study on placentome and fetus at different stages of pregnancy in Black Bengal goat, MS Thesis, Department of Animal Breeding and Genetics, Bangladesh Agricultural University.

Rahman ANMA (2002)."Changes in the Uterine Immune System during Pregnancy in Sheep". MVSc Thesis, Department of Veterinary Science, The University of Melbourne, Melbourne, Australia. P. 1-140.

Zarkawi M (1997). Monitoring the reproductive performance in Awassi ewes using progesterone radioimmunoassay. Small Ruminant Research, 26: 291-294. 